\title{
Ecosystem Water Use Efficiency in the Three-North Region of China Based on Long-Term Satellite Data
}

\author{
Qi'ao Zhang ${ }^{1}$ and Wei Chen ${ }^{2, *(D)}$ \\ 1 School of Landscape Architecture, Beijing Forestry University, Beijing 100083, China; zhangqiao@bjfu.edu.cn \\ 2 College of Geoscience and Surveying Engineering, China University of Mining \& Technology, \\ Beijing 100083, China \\ * Correspondence: chenw@cumtb.edu.cn
}

Citation: Zhang, Q.; Chen, W.

Ecosystem Water Use Efficiency in the Three-North Region of China Based on Long-Term Satellite Data. Sustainability 2021, 13, 7977. https:// doi.org/10.3390/su13147977

Academic Editor: Andrzej Wałęga

Received: 19 May 2021

Accepted: 13 July 2021

Published: 16 July 2021

Publisher's Note: MDPI stays neutral with regard to jurisdictional claims in published maps and institutional affiliations.

Copyright: (c) 2021 by the authors. Licensee MDPI, Basel, Switzerland. This article is an open access article distributed under the terms and conditions of the Creative Commons Attribution (CC BY) license (https:// creativecommons.org/licenses/by/ $4.0 /)$.

\begin{abstract}
Water use efficiency (WUE), given by the ratio between organic matter production and water consumption, could be considered as a very important ecological indicator for assessing vegetation system growth conditions by combining organic matter production and water consumption. It is especially important for regional vegetation sustainable management by creating enough organic matter with restricted water supply. Furthermore, proper analysis of WUE is vital for the evaluation and future plans of ecological restoration projects in ecologically fragile regions such as the Three-North region of China. In this study, ecosystem WUE across the Three-North region of China from 2001 to 2017 was obtained, and the variation trends and major influencing factors were also analyzed. The results demonstrated that (1) the average WUE across the Three-North region of China is $0.7376 \mathrm{~g} \cdot \mathrm{C} \cdot \mathrm{m}^{-2} \cdot \mathrm{mm}^{-1}$ with an annual increase of $0.002 \mathrm{~g} \cdot \mathrm{C} \cdot \mathrm{m}^{-2} \cdot \mathrm{mm}^{-1} \cdot \mathrm{y}^{-1}$; (2) the spatiotemporal variation trends of WUE are similar to those of gross primary production (GPP); and (3) in the southeastern parts of the Three-North region, the vegetation conditions are better with sustainable improvements, while in Xinjiang Province, the sustainable degradation areas are widely spread. The results of this research reveal large spatial heterogeneity of WUE, with high WUE mainly in the southeastern region with sufficient precipitation and afforestation programs. For those areas far away from this region, WUE is not satisfactory, suggesting that, for a sustainable vegetation growth, it is important to consider the water supply to maintain suitable vegetation cover. Furthermore, the results of this research are important for future ecological restoration and sustainable management of environment.
\end{abstract}

Keywords: water use efficiency; Three-North region; human activities

\section{Introduction}

Vegetation plays an important role in terrestrial ecosystems by absorbing carbon dioxide and consuming water during photosynthesis [1]. During the photosynthesis process, green vegetation could cause both a heating result by absorbing incident solar radiation and a cooling effect by transpiration $[2,3]$. The net radiation results are usually cooled with spatial diversities [4]. Beyond these effects, vegetation can also produce organic matter through primary production and affect the carbon balance, regulating regional and global climates [5]. During primary production, vegetation may utilize different amounts of water depending on its species composition. This aspect has to be considered with great attention in plans of reforestation. It is obvious that, for ecological restoration, in areas of a limited water supply, we should use plants with limited water consumption and relatively sufficient organic matter production $[1,6,7]$. We think that for developing plans of restoration it would be very important to characterize the different areas of interest in terms of water use efficiency (WUE). Therefore, we propose in this paper the use of an index based on the ratio of gross primary production (GPP) to evapotranspiration (ET) that could be calculated by remote sensing data and could be useful to characterize the different areas of a region in terms of water use efficiency [8-10]. 
Realizing the importance of WUE, preliminary studies focusing on leaves and individual plants were first investigated with field measurements or gas exchange methods $[11,12]$ and were later extended to local scales, such as farmland [13,14], grassland $[9,15]$, and forest $[8,16-19]$. However, these measurements are largely restricted to small scales. With the development of remote sensing techniques, global-scale productions of GPP and ET with sufficient accuracies have been produced, providing powerful tools to evaluate regional and even global ecosystem WUEs [20-24]. Both natural and anthropogenic factors could affect WUE. Sun et al. [25] discovered that WUE shows a negative correlation with annual precipitation and temperature in China. Lu et al. [26] found that the leaf area index, soil moisture, and vapor pressure may affect WUE. Other studies found that drought [27], aerosols [28], and $\mathrm{CO}_{2}$ [29] are possible influencing factors. In addition to these natural factors, human activities may affect WUE through urban construction, land reclamation, and ecological restoration projects [30]. For example, Du et al. [31] found that the contribution of natural factors to WUE variation in northern China was approximately $84 \%$, while the remaining contribution comes from afforestation and other human activities. In some ecologically fragile regions, human activities could contribute $80 \%$ to WUE variation [32]. Furthermore, the effects of natural and human activities may even counteract each other, making WUE variation more complicated [22]. Therefore, deeply investigating ecosystem WUE in regions is highly important and meaningful to evaluate the effects of these large scales of ecological restoration programs.

The Three-North region (northeast, north, and northwest) of China is a typical ecologically fragile area experiencing serious environmental problems such as desertification and land degradation [33]. Acting as a connection between China and Europe, it has influenced the global economy since ancient times. With the implementation of the "One Belt One Road Initiative", the environmental problem of the Three-North region has attracted increasing attention [34,35]. For example, overgrazing and grasslands reclamation make this area more vulnerable [36]. To overcome these problems, China has implemented a series of ecological projects since 1979 to restore vegetation cover in this region by planting trees on a large area [37]. However, effects of these projects have raised wide controversies, as the limited precipitation (less than $400 \mathrm{~mm}$ ) in the region may not be enough to support such large scales of afforestation. Cao [38] proposed that the limited precipitation and high potential ET here may even deteriorate the ecological environment. Other studies have different views, and debates have been raised [39-42]. The main aim of this study was to assess the spatial dynamics of WUE in the Three-North region of China to evaluate the vegetation restoration effects in the ecologically fragile region by: (1) analyzing the spatiotemporal variations of WUE in the Three-North region of China; (2) investigating the fluctuation and sustainability trends of WUE in this region; and (3) studying the influencing factors of WUE and the WUE of different vegetation covers.

\section{Data and Methods}

\subsection{Study Area}

The Three-North region $\left(73^{\circ} 26^{\prime} \mathrm{E}-127^{\circ} 50^{\prime} \mathrm{E}, 33^{\circ} 30^{\prime} \mathrm{E}-50^{\circ} 12^{\prime} \mathrm{E}\right)$ is located in the ecologically fragile area of China including the western part of northeastern China, northern China and most of the northwestern region, as shown in Figure 1. This region covers 551 counties in 13 provinces, covering an area of more than 4 million square kilometers, accounting for $42.4 \%$ of the country's total land area. The climates of the Three-North region are quite different, including arid climate, semiarid climate, and semiarid and semihumid climate. Arid and semiarid regions account for two-thirds of the Three-North region. From the northeast end to the southwest section, the average temperature ranges from $-2{ }^{\circ} \mathrm{C}$ to $14{ }^{\circ} \mathrm{C}$, and the temperature in most areas ranges from $2{ }^{\circ} \mathrm{C}$ to $5^{\circ} \mathrm{C}$. The precipitation decreases from east to west and from south to north, and the average annual precipitation in most areas is $20 \sim 450 \mathrm{~mm}$. Affected by precipitation, the types of natural vegetation from east to west are forest, forest-grassland, grassland, and desert. The topographical features 
of this area are also very complex. The overall terrain is low in the east and high in the west, mainly including plains, plateaus, mountains, basins, and other topographies.

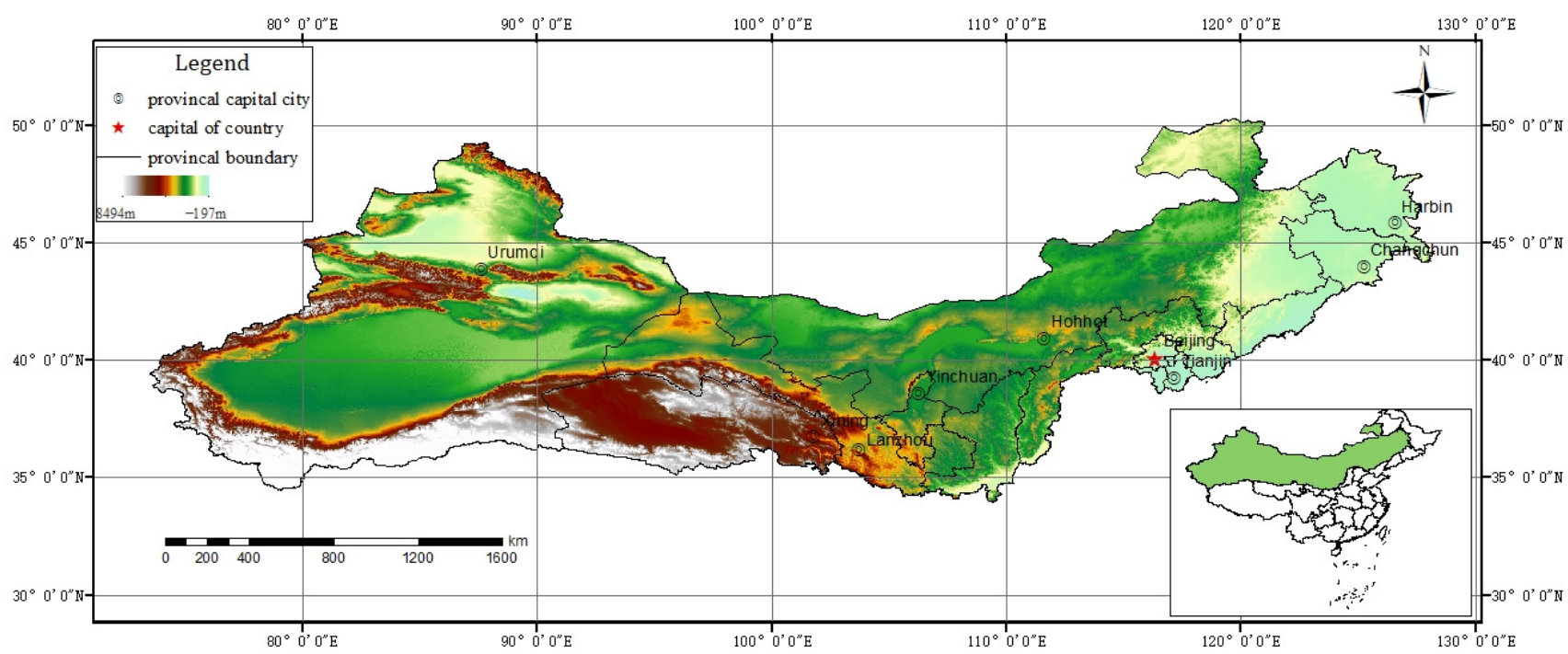

Figure 1. Location of the Three-North region of China.

\subsection{Data}

In this study, the Global Land Surface Satellite (GLASS) Gross Primary Production (GPP) and Evapotranspiration (ET) datasets from 2001 to 2017 with a spatial resolution of $0.05^{\circ}$ and a temporal resolution of 8 days were adopted to calculate WUE. The GLASS GPP product was produced with a Bayesian multialgorithm integration method combining light use efficiency models and has been validated worldwide with high accuracy [43] The GLASS ET product was produced by integrating five latent heat flux algorithms and AVHRR, MODIS, and MERRA reanalysis data with Bayesian algorithms [44]. To classify the underlying land cover types in the Three-North region, MODIS land cover data (MCD12C1) with a spatial resolution of $0.05^{\circ}$ were selected. The MCD12C1 product has divided land cover into 17 classes, as shown in Figure 2. The major land cover types in this region are barren land $(41.01 \%)$ and grasslands $(36.70 \%)$. To quantify the influences of nature and human activities, meteorological data (temperature and precipitation) developed by Peng et al. [45] with a spatial resolution of $0.5^{\prime}$ were used to calculate natural contributions.
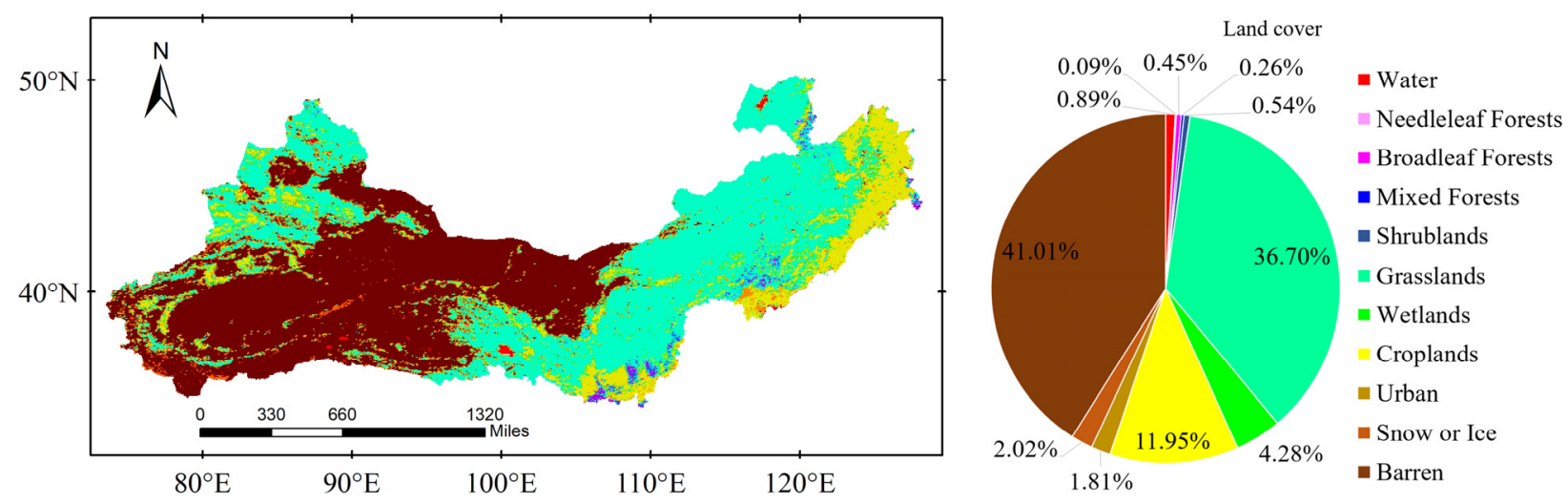

Figure 2. Land cover map and statistics of the Three-North region of China. 


\subsection{Analytical Methods}

\subsubsection{Calculation of WUE}

Ecosystem WUE can be calculated by the ratio of GPP per unit ET as follows:

$$
\mathrm{WUE}=\frac{\mathrm{GPP}}{\mathrm{ET}},
$$

\subsubsection{Trend Analytical Methods}

In this study, the variation trends of ecosystem WUE were analyzed by the combination of Theil-Sen median trend analysis and the Mann-Kendall test. Theil-Sen median trend analysis is a widely used nonparametric estimation method for long-term data record analysis as follows:

$$
\beta=\operatorname{Median}\left(\frac{x_{j}-x_{i}}{j-i}\right), \forall j>i,
$$

where $0<i<j<n, n$ is the length of the data series, $i$ and $j$ represent the index of the year, and $x_{i}$ and $x_{j}$ are the WUE values of the $i$ th and $j$ th years, respectively.

Theil-Sen trend analysis can capture only the trends of a time series. However, it cannot represent the significance level of this trend. Therefore, the Mann-Kendall test is adopted to judge the significance level of a time series. For a time series $\left\{x_{i}\right\}(i=1,2, \cdots, n)$, the statistics of the variation trend can be defined as $Z$ :

$$
Z=\left\{\begin{array}{c}
\frac{S-1}{\sqrt{\operatorname{VAR}(S)}}, S>0 \\
0, S=0 \\
\frac{S+1}{\sqrt{\operatorname{VAR}(S)}}, S<0
\end{array},\right.
$$

where

$$
\begin{gathered}
S=\sum_{i=1}^{n-1} \sum_{j=i+1}^{n} \operatorname{sgn}\left(x_{j}-x_{i}\right), \\
\operatorname{sgn}\left(x_{j}-x_{i}\right)=\left\{\begin{array}{c}
1, x_{j}-x_{i}>0 \\
0, x_{j}-x_{i}=0 \\
-1, x_{j}-x_{i}<0
\end{array}\right. \\
\operatorname{VAR}(S)=\left(n(n-1)(2 n+5)-\sum_{i=1}^{m} t_{i}\left(t_{i}-1\right)\left(2 t_{i}+5\right)\right) / 18,
\end{gathered}
$$

where $n$ is the number of elements in this time series, $m$ is the number of repeated data in this time series, and $t_{i}$ is the number of duplicates in group $i$. For a given significance level of $\alpha(0.01,0.05,0.1)$, if the value of $|Z|>Z_{1-\frac{\alpha}{2}}$, it means the increasing or decreasing trend of the time series is significant; otherwise, the variation trend is insignificant.

\subsubsection{Variation Coefficients}

To quantitatively characterize the degree of interannual WUE variations, the variation coefficient (VC) is used as follows:

$$
\mathrm{VC}_{\mathrm{WUE}}=\frac{\sigma_{\mathrm{WUE}}}{\overline{\overline{\mathrm{WUE}}}}
$$

where $\sigma_{\text {WUE }}$ is the standard deviation of the WUE time series from 2001 to 2017, and $\overline{\text { WUE }}$ is the average WUE over the time range. The smaller the value of $\mathrm{VC}_{\text {WUE }}$. is, the more stable the WUE time series is. Otherwise, the WUE time series has experienced large volatility. 


\subsubsection{Hurst Exponent (Sustainability Trend)}

The Theil-Sen trend, Mann-Kendall test, and VC are used to determine the variation trend in the past. In addition of past variation trends, it is also meaningful to address the future variation trends. Here, we use the Hurst exponent to predict whether the variation trends of the past will continue (sustainability) or not. To predict the future variation trend, the Hurst exponent was adopted in this study. The major procedure used to calculate the Hurst exponent in this study was as follows:

(1) Obtain the annual average WUE time series,

$$
\left\{\operatorname{WUE}_{(t)}\right\}, t=1,2, \cdots, n,
$$

(2) Calculate the average WUE over the time range,

$$
\overline{\operatorname{WUE}}_{(\tau)}=\frac{1}{\tau} \sum_{t=1}^{\tau} \operatorname{WUE}_{(t)} \quad \tau=1,2, \cdots, n,
$$

(3) Calculate the accumulated deviation of WUE over the time range,

$$
X_{(t, \tau)}=\sum_{t=1}^{t}\left(\operatorname{WUE}_{(t)}-\overline{\operatorname{WUE}}_{(\tau)}\right) 1 \leq t \leq \tau,
$$

(4) Create the range sequence $R_{(\tau)}$,

$$
R_{(\tau)}=\max _{1 \leq t \leq \tau} X_{(t, \tau)}-\min _{1 \leq t \leq \tau} X_{(t, \tau)} \quad \tau=1,2, \cdots, n,
$$

(5) Create the standard deviation sequence $S_{(\tau)}$,

$$
S_{(\tau)}=\left[\frac{1}{\tau} \sum_{t=1}^{\tau}\left(\operatorname{WUE}_{(t)}-\overline{\operatorname{WUE}}_{(\tau)}\right)^{2}\right]^{\frac{1}{2}} \quad \tau=1,2, \cdots, n,
$$

(6) Calculate the Hurst exponent,

$$
\frac{R_{(\tau)}}{S_{(\tau)}}=(c \tau)^{H},
$$

where $c$ is a constant, and the Hurst exponent $H$ can be calculated by fitting the equation $\log \left(\frac{R}{S}\right)=H \log \tau+H \log a$ using the least squares method. The range of Hurst exponent is $0 \sim 1$. When $H<0.5$, the time series has a trend of anticontinuity in the future, while when $H>0.5$, the time series has positive sustainability. When $H=0.5$, the time series is a random sequence.

\subsubsection{Correlation Analysis}

The Pearson coefficient is used to analyze the correlations between WUE and climate factors as follows:

$$
R=\frac{\sum(x-\bar{x})(y-\bar{y})}{\sqrt{\sum(x-\bar{x})^{2}} \sqrt{\sum(y-\bar{y})^{2}}}
$$

where $R$ is the Pearson coefficient, $x$ is the climate factor (precipitation or temperature), and $y$ represents the WUE. To calculate the significance level of correlation, a $t$-test is adopted as follows:

$$
t=\frac{R \sqrt{n-1}}{\sqrt{1-R^{2}}}
$$


where $n$ is the number of samples. For a given significance level $\alpha 1(p<0.05)$ and $\alpha 2$ $(p<0.01)$, if $t>t_{\alpha 1}$, the correlation is significant; if $t>t_{\alpha 2}$, the correlation is extremely significant. Otherwise, the correlation is not significant.

\subsubsection{Impacts of Climate Factors and Human Activities}

In this study, the multiple regression residual method was used to separate human activities and climate factors by assuming that WUE had linear correlations with the combinations of precipitation and temperature, and the residual of such correlation could be regarded as the impact of human activities:

$$
\mathrm{WUE}_{\text {Climate }}=a \times P+b \times T+c, \mathrm{WUE}_{\text {Human }}=\mathrm{WUE}-\mathrm{WUE}_{\text {Climate, }}
$$

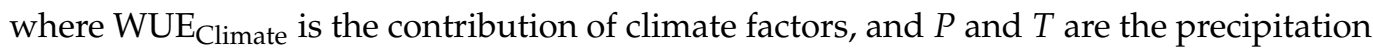
and temperature, respectively. $a, b$, and $c$ are regression coefficients, and WUE $\mathrm{Human}_{\text {in }}$ is the contribution of human activities. To evaluate the impacts of climate factors and human activities, the Sen slopes of $W U E_{C l i m a t e}$ and $W U E_{H u m a n}$ are calculated to divide their impact into seven grades, as shown in Table 1: significant inhibition, moderate inhibition, slight inhibition, almost no effect, slight promotion, moderate promotion, and moderate promotion.

Table 1. Gradings of impacts of climate factors and human activities on WUE.

\begin{tabular}{|c|c|c|c|c|c|c|c|}
\hline $\begin{array}{c}\text { Sen } \\
\left(\text { WUE } \times 10^{-2}\right)\end{array}$ & $<-2$ & $-2 \sim-1$ & $-1 \sim-0.2$ & $-0.2 \sim 0.2$ & $0.2 \sim 1$ & $1 \sim 2$ & $>2$ \\
\hline Level & $\begin{array}{l}\text { Significant } \\
\text { inhibition }\end{array}$ & $\begin{array}{l}\text { Moderate } \\
\text { inhibition }\end{array}$ & $\begin{array}{c}\text { Slight } \\
\text { inhibition }\end{array}$ & $\begin{array}{c}\text { Almost no } \\
\text { effect }\end{array}$ & $\begin{array}{c}\text { Slight } \\
\text { promotion }\end{array}$ & $\begin{array}{l}\text { Moderate } \\
\text { promotion }\end{array}$ & $\begin{array}{l}\text { Moderate } \\
\text { promotion }\end{array}$ \\
\hline
\end{tabular}

\section{Results}

\subsection{Spatial Distributions of GPP, ET, and WUE}

WUE is calculated by the ratio of GPP to ET; therefore, the spatial distribution of GPP and ET may have great influence on WUE. Figure 3 shows the spatial distributions of the annual average GPP, ET, and WUE from 2001 to 2017 over the Three-North region of China. As shown in Figure 3a, the GPP of most research areas was low (less than $\left.200 \mathrm{~g} \cdot \mathrm{C} \cdot \mathrm{m}^{-2} \cdot \mathrm{y}^{-1}\right)$, suggesting that the vegetation conditions in northwest China are very poor with very limited organic matter production. ET mainly showed a decreasing trend from approximately $900 \mathrm{~mm} \cdot \mathrm{y}^{-1}$ in the southwest to less than $50 \mathrm{~mm} \cdot \mathrm{y}^{-1}$ in the desert region in the northwest, as shown in Figure 3b. The distributions of GPP and ET demonstrated extreme spatial diversity, as the southwest of this region had both high GPP and high ET, while the northwest of this region had both low GPP and low ET. For WUE, as shown in Figure 3c, it had a similar spatial pattern as GPP, suggesting that GPP may be the major influencing factor. The spatial distribution of WUE suggested that, in those regions with extremely low water supply (desert/Gobi), vegetation primary production is limited.

\subsection{Spatiotemporal Variations in GPP, ET, and WUE}

The variation in trends of each pixel could be effectively obtained through the Sen trend analysis and the Mann-Kendall test, and the spatial variations in GPP, ET, and WUE of the Three-North region of China are shown in Figure 4. In Figure 4, only pixels passing the Mann-Kendall test (the trend is significant) are selected. As shown in Figure 4a, the southern and eastern parts of the research regions demonstrate significant increasing GPP trends, which are similar to those of WUE, as shown in Figure 4c. For ET, as shown in Figure $4 \mathrm{~b}$, regions with significant variation are much different from those of WUE and GPP. For GPP, $78.53 \%$ (21.47\%) of the Three-North region of China had an increasing (decreasing) trend, and $36.86 \%(2.94 \%)$ showed a significant increasing trend. For ET, $69.97 \%(30.03 \%)$ of the total research area showed an increasing (decreasing) trend, and $5.28 \%(0.01 \%)$ showed 
a significant increasing (decreasing) trend. For WUE, 67.60\% (32.4\%) of the total research region showed an increasing (decreasing) trend, and $32.44 \%$ (13.04\%) of the research region showed a significant increasing (decreasing) trend. For most parts of Three-North region, the variation trends of WUE are not significant. In western parts, mainly negative variation trends were discovered. It is especially important that, in southeastern parts of Three-North region, large areas of significant increasing trends were discovered. This area is the core areas of ecological restorations and abundant precipitation, suggesting that those large scales of ecological restorations were implemented across the entire Three-North region, and the most effective areas are still in the southwestern boundary regions. For the whole Three-North region, GPP, ET, and WUE all showed small increasing trends, as shown in Figure 5.
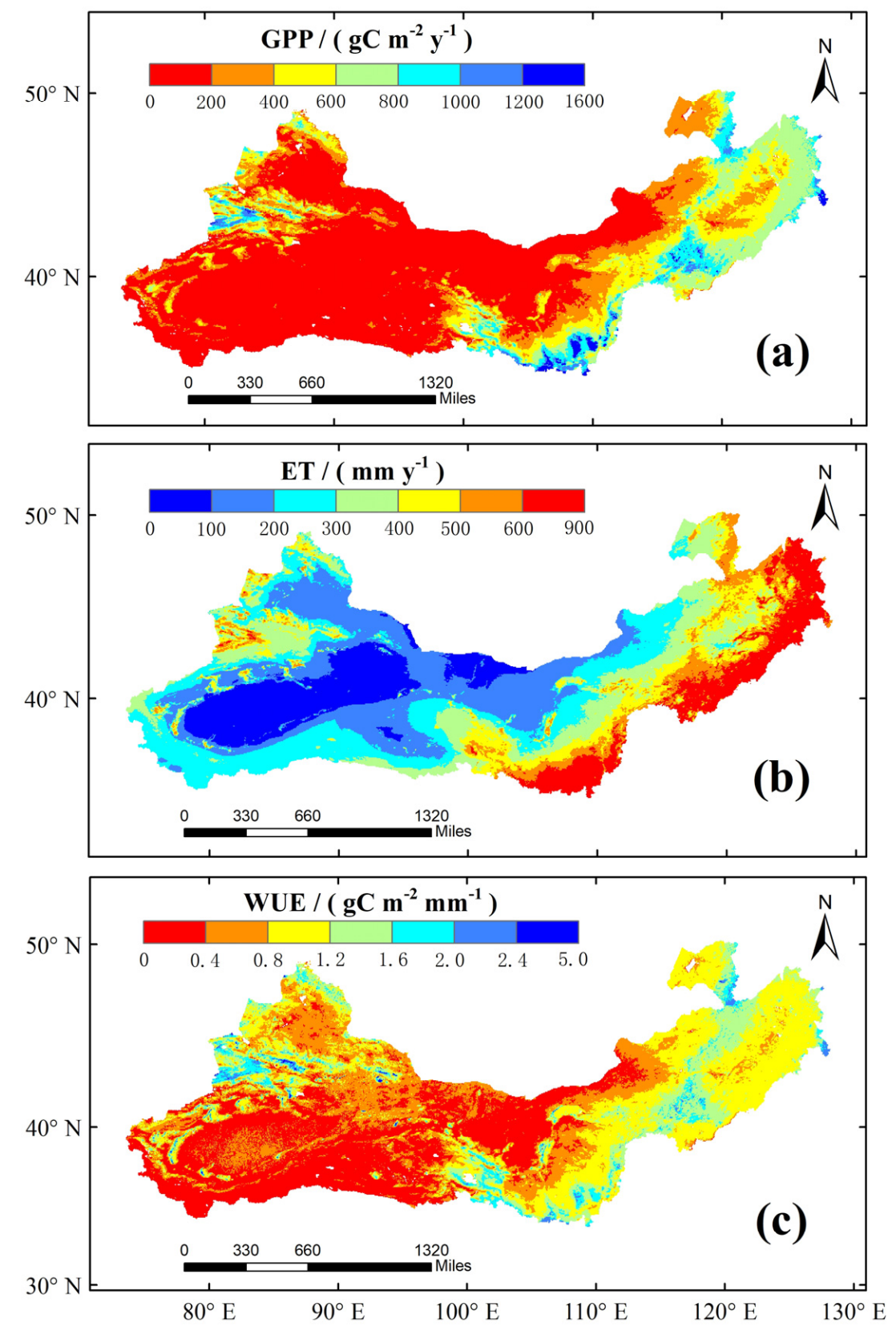

Figure 3. Spatial distributions of annual average GPP (a), ET (b), and WUE (c) in the Three-North region of China from 2001 to 2017. 

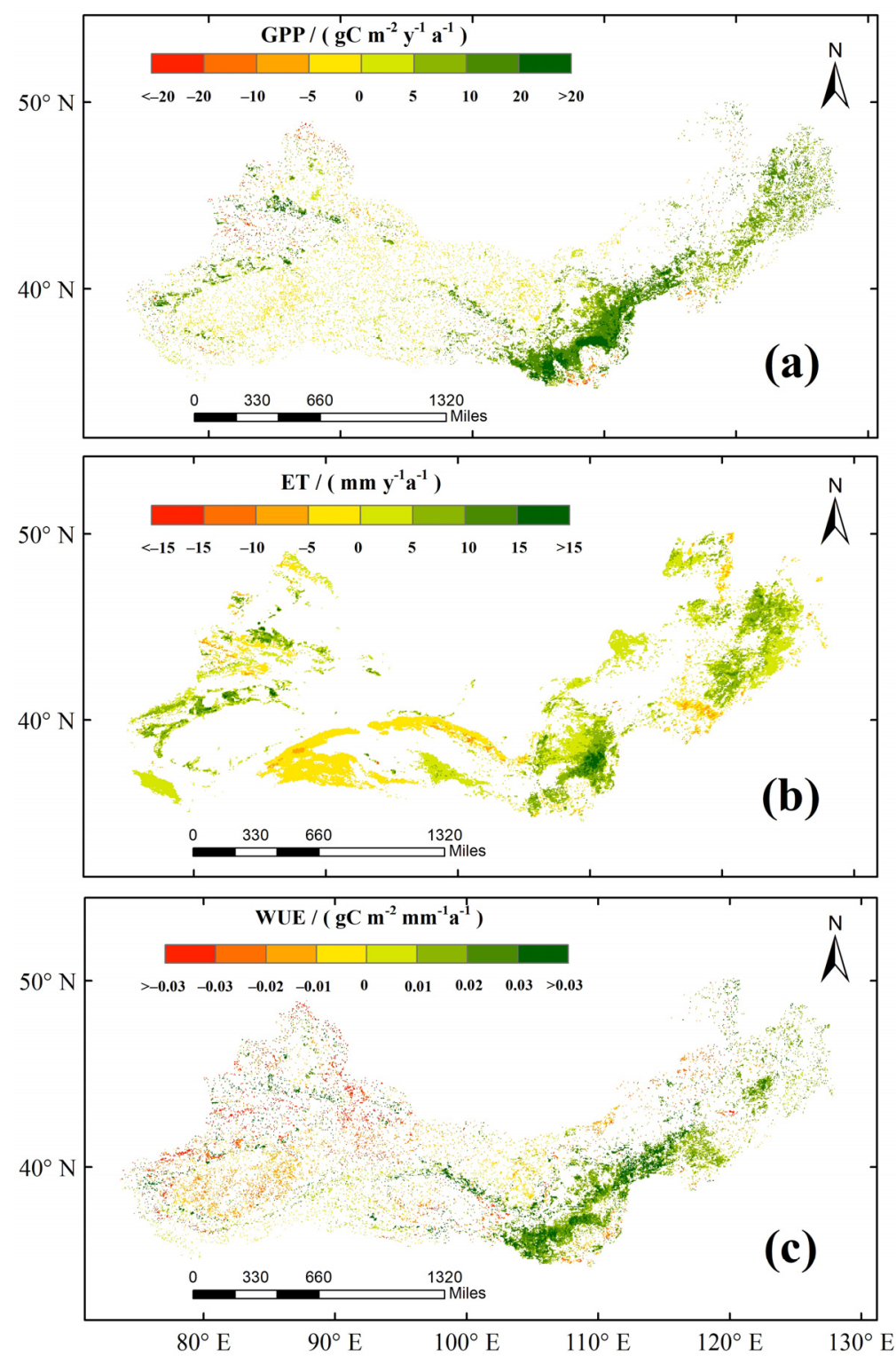

Figure 4. Spatial variations in GPP (a), ET (b), and WUE (c) of the Three-North region of China.

\subsection{The Fluctuation Analysis of GPP, ET, and WUE}

The fluctuations in GPP, ET, and WUE across the Three-North region of China were shown by the VCs. In this study, the VCs were categorized into five grades: high fluctuation, moderate-high fluctuation, moderate fluctuation, moderate-low fluctuation, and low fluctuation, based on the natural breakpoint method, as shown in Figure 6. For GPP, approximately $38.30 \%$ of the total area had low fluctuations, while only $1.43 \%$ of the total area had high fluctuations. The statistics of WUE were similar to those of GPP. For ET, $28.71 \%$ of the total area had low fluctuations, while $5.19 \%$ of the total area had high fluctuations. For GPP and WUE, the low fluctuations was mainly distributed in the southern and eastern parts of the research region. The high fluctuations were mainly located at the border areas of Xinjiang Province. For ET, the desert and Gobi regions in the western part of the research area showed large fluctuations, suggesting that the water conditions in the arid areas had large interannual variations. These results suggest that the vegetation growth conditions and WUE in the eastern and southern parts of this region with relatively abundant precipitation conditions are more stable than the regions with limited water supplies. 

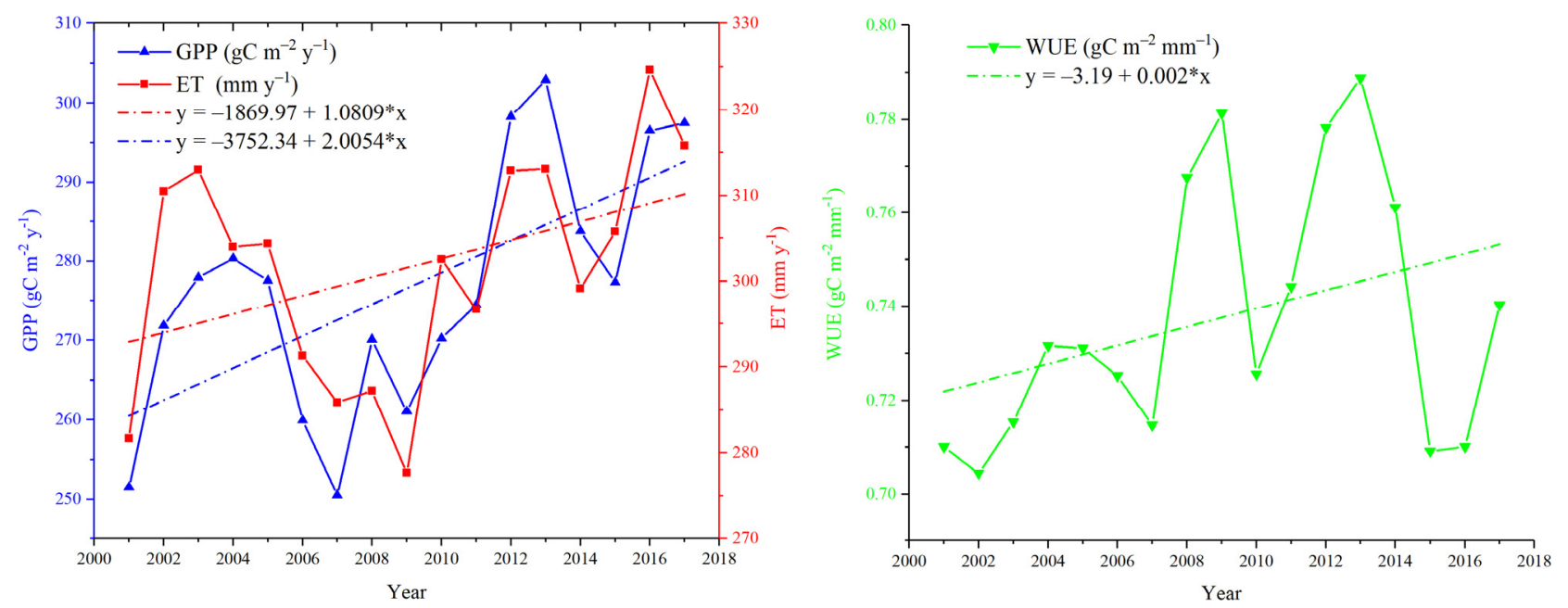

Figure 5. Overall temporal variations in GPP, ET, and WUE of the Three-North region of China.
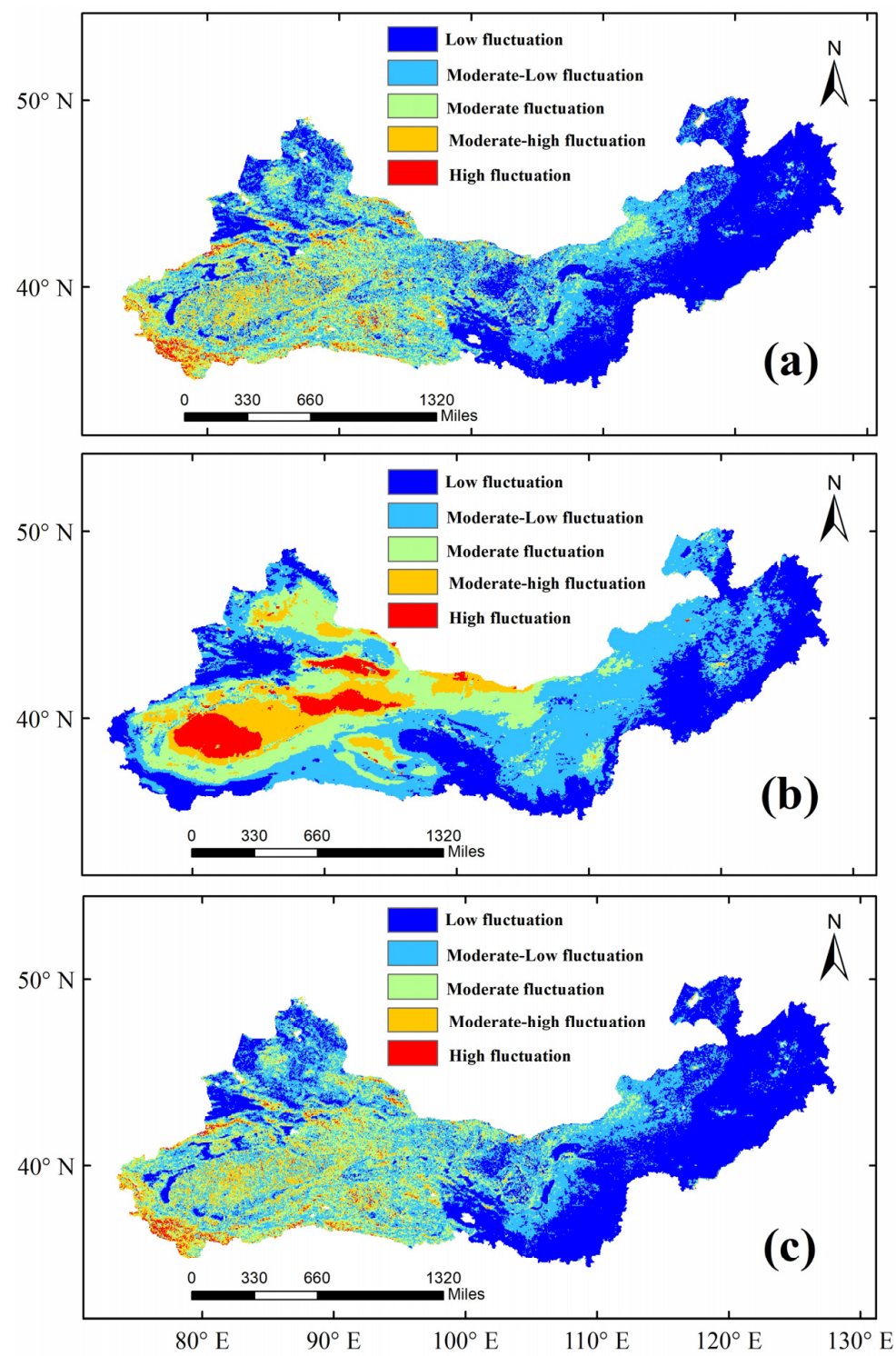

Figure 6. Spatial distributions of GPP (a), ET (b), and WUE (c) fluctuations across the Three-North region of China. 


\subsection{The Sustainability Analysis of GPP, ET, and WUE}

As shown in Figure 7, the sustainability of GPP, ET, and WUE is divided into five categories, as shown in Table 2. For GPP, in the Three-North region, approximately $38.04 \%$ of the total area showed sustainability and degradation, mainly in the western parts (Xinjiang Province). Additionally, approximately $56.56 \%$ of the total area showed sustainability and improvement. For ET, the corresponding numbers were $30.20 \%$ and $58.02 \%$, respectively. For WUE, $43.82 \%$ of the total area showed sustainability and degradation, and $51.15 \%$ showed sustainability and improvement. For spatial distribution, the sustainability and improved areas of GPP and WUE were mainly located in the eastern and southeastern border regions, while the sustainability and degraded areas were mainly located in the western regions, suggesting great ecological pressure in the western arid regions of China. For ET, the situations were obviously different from the sustainability and degradation regions, mainly in Qinghai Province and parts of the eastern regions. The sustainability analysis further indicated that Xinjiang Province and Inner Mongolia should pay more attention on vegetation growth conditions in the future. In southeastern parts, the effects of ecological restoration projects are obvious, with large areas of sustainability and improvement in the future. These results all suggested that the ecological restoration projects in the eastern parts effectively improved the local vegetation conditions in the present and in the future. However, in the western parts, the effects were not as good as in the eastern parts. Furthermore, the variation trends in the future are not satisfying.

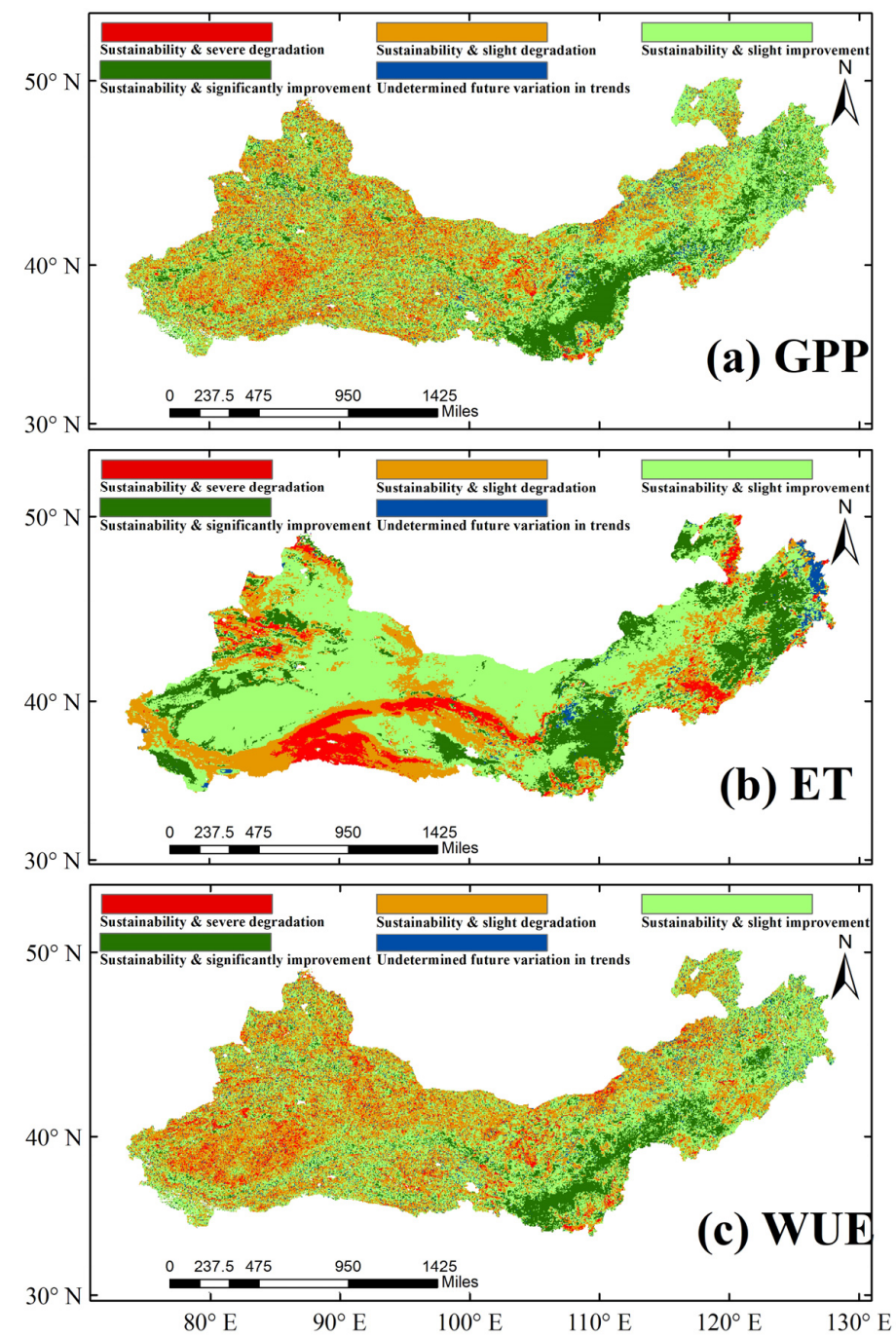

Figure 7. Sustainability analysis of GPP (a), ET (b), and WUE (c) of the Three-North region of China. 
Table 2. Sustainability and variation trend analysis of GPP, ET, and WUE in the Three-North region of China.

\begin{tabular}{|c|c|c|c|c|c|c|}
\hline Categories & Sen Standard & MK Test Standard & Hurst Exponent & GPP & ET & WUE \\
\hline $\begin{array}{c}\text { Sustainability and significant } \\
\text { degradation }\end{array}$ & $\beta>0$ & $|Z|>1.96$ & $H>0.5$ & $3.75 \%$ & $7.79 \%$ & $5.28 \%$ \\
\hline $\begin{array}{c}\text { Sustainability and slight } \\
\text { degradation }\end{array}$ & $\beta \leq 0$ & $|Z| \leq 1.96$ & $H>0.5$ & $34.29 \%$ & $22.41 \%$ & $38.54 \%$ \\
\hline $\begin{array}{c}\text { Sustainability and slight } \\
\text { improvement }\end{array}$ & $\beta \leq 0$ & $|Z| \leq 1.96$ & $H>0.5$ & $42.77 \%$ & $49.92 \%$ & $40.00 \%$ \\
\hline $\begin{array}{c}\text { Sustainability and significant } \\
\text { improvement }\end{array}$ & $\beta>0$ & $|Z|>1.96$ & $H>0.5$ & $13.79 \%$ & $18.10 \%$ & $11.15 \%$ \\
\hline $\begin{array}{l}\text { Undetermined future variation } \\
\text { in trends }\end{array}$ & - & - & $<H 0.5$ & $5.40 \%$ & $1.78 \%$ & $5.03 \%$ \\
\hline
\end{tabular}

\subsection{Analysis of Influencing Climate Factors of Vegetation WUE Change}

The spatial distributions of the $t$-test analysis of the correlation results between WUE and climate factors (annual precipitation and annual average temperature) are shown in Figure 8 . In the northern and eastern parts of the Three-North region, WUE mainly showed a negative correlation with temperature. A positive correlation with temperature mainly occurred in the western and southwestern parts. These results suggested that in eastern parts of Three-North region, the increase of temperature may both increase GPP and ET, but the net effects in WUE was negative, while in western parts, the increase of temperature (usually with increase of temperature) would slightly increase WUE. The statistics showed that $53.61 \%$ of the total area had positive correlations between WUE and temperature, with $3.19 \%$ and $0.91 \%$ of the total area showing significant $(p<0.05)$ and extremely significant positive correlations $(p<0.01$ ). Only $1.66 \%$ and $0.45 \%$ of the total area showed significant $(p<0.05)$ and extremely significant negative correlations $(p<0.01)$. For precipitation, the western parts of the Three-North region mainly showed negative correlations between precipitation and WUE, while the eastern parts mainly showed positive correlations, as shown in Figure $8 \mathrm{~b}$. A total of $44.13 \%$ of the total area showed positive correlations between precipitation and WUE, with $2.29 \%$ and $0.63 \%$ of the total area showing significant $(p<0.05)$ and extremely significant $(p<0.05)$ positive correlations, respectively. A total of $4.36 \%$ and $1.5 \%$ of the total area showed significant $(p<0.05)$ and extremely significant $(p<0.05)$ negative correlations, respectively, between WUE and precipitation. The spatial distribution pattern of correlations between precipitation and WUE suggested that the increase of precipitation in eastern parts will significant increase WUE, while in western parts, the effects are complex.

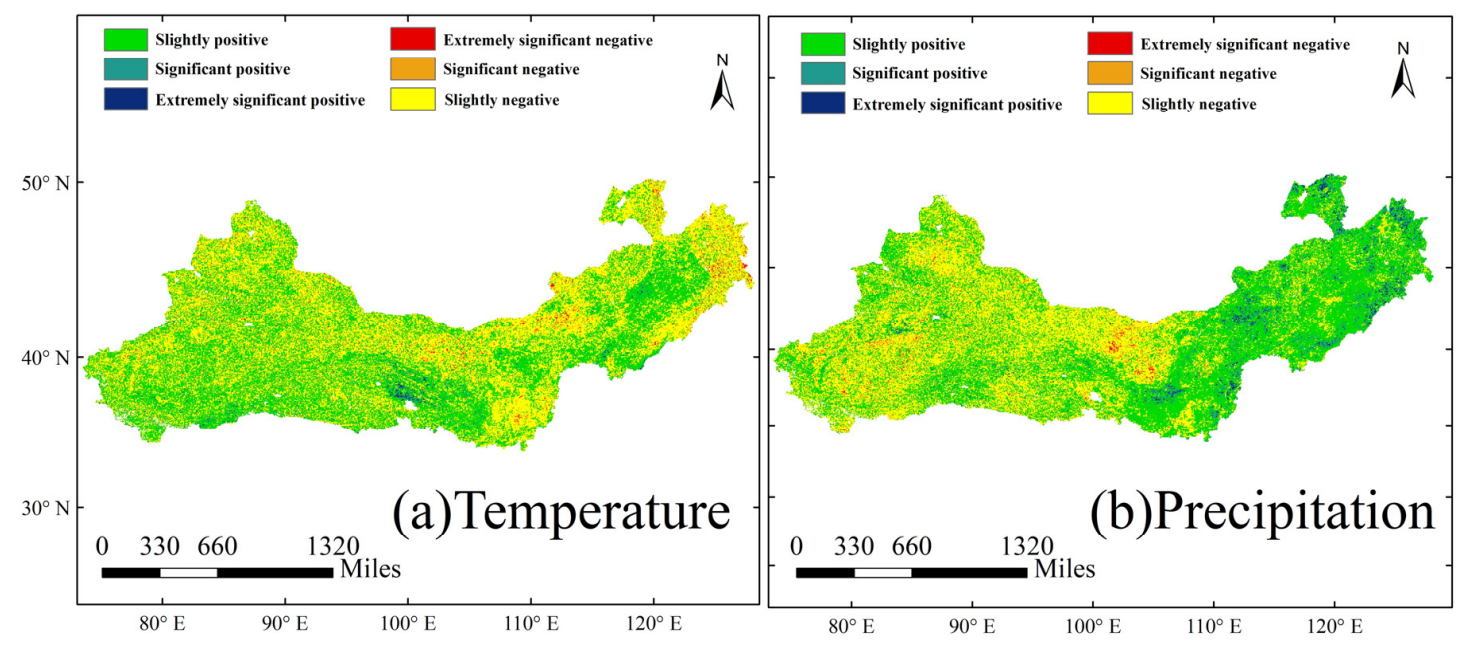

Figure 8. Spatial distributions of the correlations between the annual WUE and climate factors ((a): annual average temperature; (b): annual precipitation). 


\subsection{WUE Variations in Different Vegetation Covers}

Different vegetation cover may also influence WUE, as forest species, grass, and shrubs may consume different amounts of water to produce per unit organic matter. Therefore, it is important to investigate the WUE characteristics in different vegetation types. As shown in Figure 9, broadleaf forest had the largest WUE (approximately $1.8 \mathrm{~g} \cdot \mathrm{C} \cdot \mathrm{m}^{-2} \cdot \mathrm{mm}^{-1}$ over the entire research time range), followed by mixed forests, needleleaf forests, shrublands, wetlands, croplands, grasslands, and barren forests (approximately $0.3 \mathrm{~g} \cdot \mathrm{C} \cdot \mathrm{m}^{-2} \cdot \mathrm{mm}^{-1}$ ). During the research time period, vegetation lands mainly showed increasing trends of WUE, while barren land areas showed a decreasing trend. Forests are more effective in utilizing limited water supply to produce organic matters, suggesting that those regions with more forests have large WUE. The results in Figures 3 and 4 all agree with this. However, the growth of wooden trees needs abundant water supply for transpiration, which, therefore, limits the distribution of wooden trees in western parts. Therefore, only those regions with enough precipitation can afford the growth of wooden trees. For those more arid regions, only shrub or grasslands could grow; the WUE will be far less than forest regions, though it still showed slowly increasing trends.

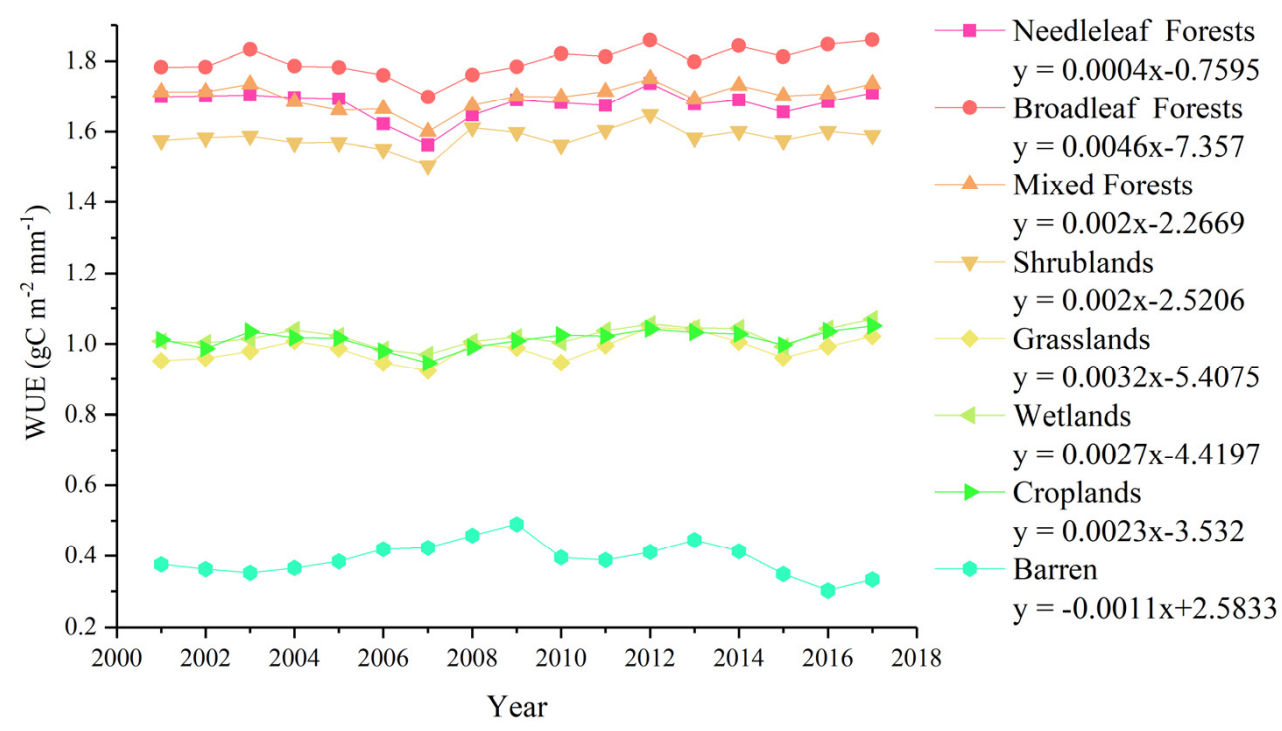

Figure 9. Annual WUE values of different land cover types in the Three-North region of China.

\subsection{Effects of Human Activities and Climate Factors on WUE}

There is great spatial heterogeneity in the impact of climate factors and human activities on the spatial distribution of WUE across the Three-North region of China, as shown in Figure 10. For the Three-North region, climate factors mainly have almost no effect $(54.97 \%)$ or a slight promotion $(24.31 \%)$ on the WUE of this region. Less than $20 \%$ of the total area showed inhibitory effects of climate factors. For human activities, the result was obviously different from that of climate factors. First, the area with almost no effect was reduced to $20.18 \%$, while the areas with slight promotion, moderate promotion, and significant promotion increased to $24.39 \%, 12.53 \%$, and $7.34 \%$, respectively, suggesting that, in this region, human activities have a great impact on the vegetation conditions, similar to the results obtained from Du et al. [31]. For example, the significant promotion region of human activities was mainly distributed around Shaanxi and Shanxi in the southeastern parts of the Three-North region. The significant promotion region was consistent with those regions with large scales of afforestation program, as there are plenty of precipitation and irrigation conditions in these regions, suggesting that human activities have greatly promoted vegetation conditions here. 


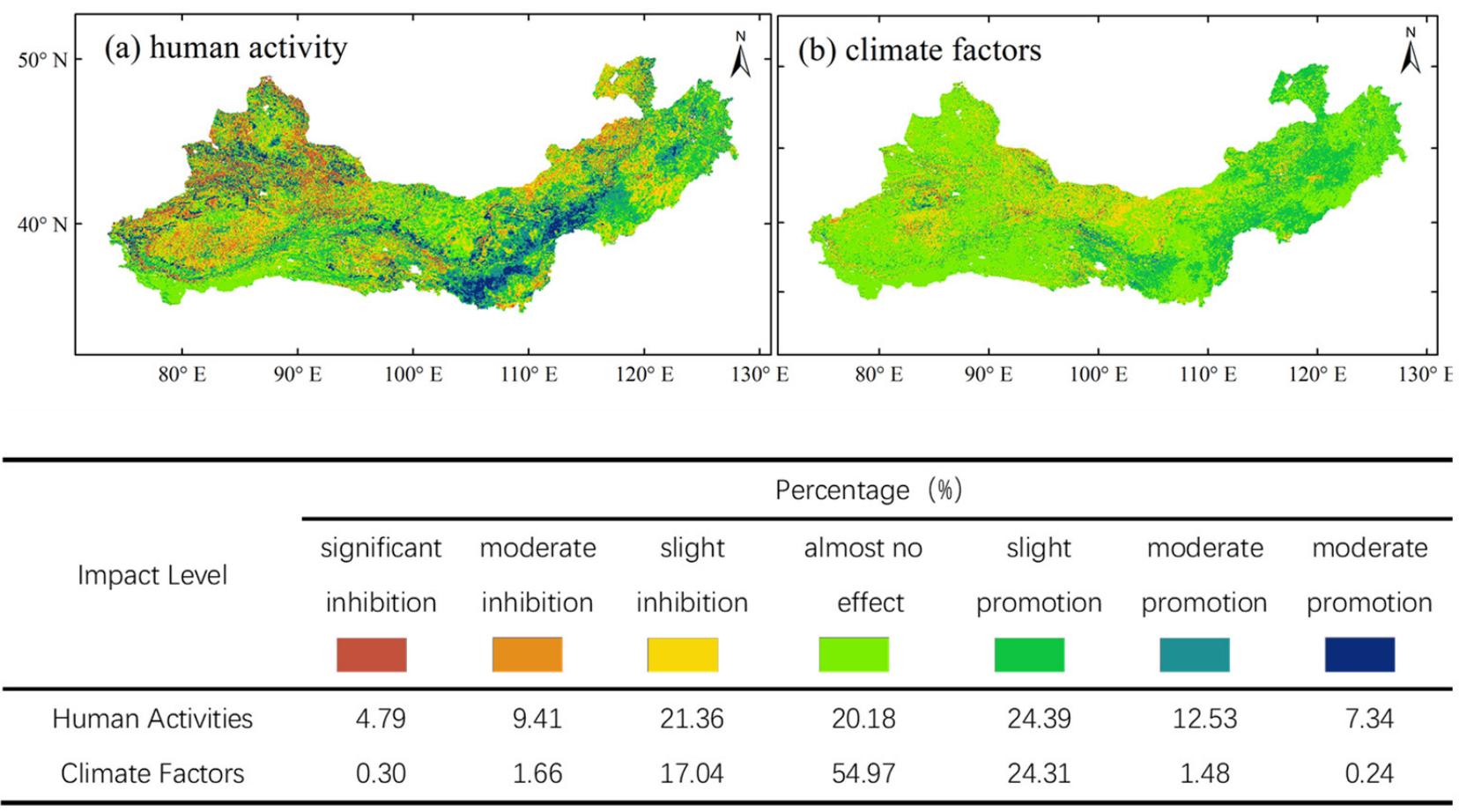

Figure 10. Spatial distributions of human activity and climate factors on WUE.

\section{Discussion}

\subsection{Comparisons of WUE over China}

WUE is the ratio of GPP and ET, suggesting that both GPP and ET are potential control factors. For example, GPP is found to be the main control factor in humid regions, as the growth of GPP may be much larger than that of ET [10], suggesting that GPP variation trends are very similar to those of WUE [46], which is consistent with this study. Previous studies globally [47-49], in China [20,50,51], and in parts of China [31,32] have suggested that the overall average WUE ranges from 1.0 to $2.4 \mathrm{~g} \cdot \mathrm{C} \cdot \mathrm{m}^{-2} \cdot \mathrm{mm}^{-1}$. Our results are different from most previous studies, as barren lands occupied $41.01 \%$ of the total research areas with very low WUE (less than $\mathrm{g} \cdot \mathrm{C} \cdot \mathrm{m}^{-2} \cdot \mathrm{mm}^{-1}$ ), making the WUE values of the whole research region very low. However, the total small increasing trend $\left(0.002 \mathrm{~g} \cdot \mathrm{C} \cdot \mathrm{m}^{-2} \cdot \mathrm{mm}^{-1} \cdot \mathrm{y}^{-1}\right)$ was very similar to previous studies $[51,52]$. These results suggested that there was large spatial diversity of WUE in different regions. However, the overall WUE is increasing slowly.

\subsection{Potential Link to Sustainable Management of Environment}

Ecosystem WUE is critical for the sustainable management of environment for waterlimited areas and irrigation-dependent areas. For example, Salazar-Moreno et al. [53] found that excess water extraction has depleted the water table to an alarming level, threating the water supply of other sectors of agriculture, posing a question on the sustainable use of water in Mexico. Stroosnijder et al. [54] pointed out that, in dry land areas, it is more urgent to improve water use efficiency to increase crop production per drop. Hence, it is important to prioritize environmental sustainability by increasing water use efficiency in agriculture [55-57]. Furthermore, WUE is also useful for sustainable environmental management in water supply-limited areas. Ma et al. [58] found that the seasonal variations of WUE in a desert riparian forest are correlated to the irrigation conditions. Emmerich [59] discovered that ecosystem WUE in semiarid shrubland and grassland communities have some relationships with the vegetation types. Furthermore, ecosystem WUE is found to keep stable at slight drought conditions and decrease greatly at moderate to severe drought conditions [60], having some implications for ecosystem sustainable development. 
Therefore, WUE at leaf scale, field scale, and ecosystem scale is a useful indicator to measure the trade-off between carbon gain and water loss, helping people to keep a balance between these two factors and continue environmentally sustainable development.

\subsection{Limitations and Future Perspectives}

This research has some limitations. First, climate factors were limited to temperature and precipitation. As shown in Guo et al. [32] and Li et al. [61], climate factors are complex and fickle, making the separation of natural and anthropogenic factors difficult. Second, the scale of WUE was $1 \mathrm{~km}$, while the vegetation cover at this scale may be different, causing a scale effect and making the result complex. Therefore, to better evaluate ecosystem WUE and its influencing factors, more accurate climate factors and more spatially accurate data are necessary.

\section{Conclusions}

WUE is an important ecosystem indicator reflecting the carbon-water cycle of vegetation cover, which is of much potential meaning for both ecological restoration and environmental management. In this study, with the help of long-term satellite observations, the WUE and its spatial variation trends were analyzed across the Three-North region of China. The results revealed a great spatial diversity of WUE with similar variation trends of GPP, suggesting that GPP was the major control factor of WUE. In the Three-North region of China, the WUE value was lower than the national average due to the large area of barren lands, reducing the absolute value in this region. Despite that, the WUE increased slowly at a rate of $0.002 \mathrm{~g} \cdot \mathrm{C} \cdot \mathrm{m}^{-2} \cdot \mathrm{mm}^{-1} \cdot \mathrm{y}^{-1}$. The fluctuation and sustainability analysis of WUE further indicated that the eastern and southeastern parts of the Three-North region had both few fluctuations and low sustainable improvements, while the western parts showed more fluctuation and sustainable degradation. These results are of great importance for future ecological restoration programs in this region, as the vegetation growth conditions here have great spatial heterogeneity.

Author Contributions: Writing, visualization, formal analysis, Q.Z.; conceptualization, methodology, W.C. All authors have read and agreed to the published version of the manuscript.

Funding: This research was funded by the National Natural Science Foundation of China, grant number 41701391.

Institutional Review Board Statement: Not applicable.

Informed Consent Statement: Not applicable.

Data Availability Statement: Data sharing not applicable.

Conflicts of Interest: The authors declare no conflict of interest.

\section{References}

1. Jin, Z.; Liang, W.; Yang, Y.; Zhang, W.; Yan, J.; Chen, X.; Li, S.; Mo, X. Separating Vegetation Greening and Climate Change Controls on Evapotranspiration trend over the Loess Plateau. Sci. Rep. 2017, 7, 8191. [CrossRef]

2. Chen, C.; Park, T.; Wang, X.; Piao, S.; Xu, B.; Chaturvedi, R.K.; Fuchs, R.; Brovkin, V.; Ciais, P.; Fensholt, R.; et al. China and India lead in greening of the world through land-use management. Nat. Sustain. 2019, 2, 122-129. [CrossRef] [PubMed]

3. Ge, J.; Guo, W.; Pitman, A.J.; De Kauwe, M.G.; Chen, X.; Fu, C. The Nonradiative Effect Dominates Local Surface Temperature Change Caused by Afforestation in China. J. Clim. 2019, 32, 4445-4471. [CrossRef]

4. Huang, M.; Piao, S.; Zeng, Z.; Peng, S.; Ciais, P.; Cheng, L.; Mao, J.; Poulter, B.; Shi, X.; Yao, Y.; et al. Seasonal responses of terrestrial ecosystem water-use efficiency to climate change. Glob. Chang. Biol. 2016, 22, 2165-2177. [CrossRef] [PubMed]

5. Delgado, R.C.; Pereira, M.G.; Teodoro, P.E.; dos Santos, G.L.; de Carvalho, D.C.; Magistrali, I.C.; Vilanova, R.S. Seasonality of gross primary production in the Atlantic Forest of Brazil. Glob. Ecol. Conserv. 2018, 14, e00392. [CrossRef]

6. He, B.; Chen, A.; Wang, H.; Wang, Q. Dynamic Response of Satellite-Derived Vegetation Growth to Climate Change in the Three North Shelter Forest Region in China. Remote Sens. 2015, 7, 9998-10016. [CrossRef]

7. Li, Y.; Wang, X.; Chen, Y.; Wang, M. Land surface temperature variations and their relationship to fractional vegetation coverage in subtropical regions: A case study in Fujian Province, China. Int. J. Remote Sens. 2019, 41, 2081-2097. [CrossRef] 
8. $\quad$ Song, Q.H.; Fei, X.H.; Zhang, Y.P.; Sha, L.Q.; Liu, Y.T.; Zhou, W.J.; Wu, C.S.; Lu, Z.Y.; Luo, K.; Gao, J.B.; et al. Water use efficiency in a primary subtropical evergreen forest in Southwest China. Sci. Rep. 2017, 7, 43031. [CrossRef]

9. Wang, Y.; Ma, Y.; Li, H.; Yuan, L. Carbon and water fluxes and their coupling in an alpine meadow ecosystem on the northeastern Tibetan Plateau. Theor. Appl. Climatol. 2020, 142, 1-18. [CrossRef]

10. Yang, Y.; Guan, H.; Batelaan, O.; McVicar, T.R.; Long, D.; Piao, S.; Liang, W.; Liu, B.; Jin, Z.; Simmons, C.T. Contrasting responses of water use efficiency to drought across global terrestrial ecosystems. Sci. Rep. 2016, 6, 23284. [CrossRef]

11. Martin, B.; Thorstenson, Y.R. Stable Carbon Isotope Composition (delta-c-13), Water Use Efficiency, and Biomass Productivity of Lycopersicon esculentum, Lycopersicon pennellii, and the F1 Hybrid. Plant Physiol. 1988, 88, 213-217. [CrossRef]

12. Donovan, L.A.; Dudley, S.A.; Rosenthal, D.M.; Ludwig, F. Phenotypic selection on leaf water use efficiency and related ecophysiological traits for natural populations of desert sunflowers. Oecologia 2007, 152, 13-25. [CrossRef]

13. Wang, H.; Li, X.; Tan, J. Interannual Variations of Evapotranspiration and Water Use Efficiency over an Oasis Cropland in Arid Regions of North-Western China. Water 2020, 12, 1239. [CrossRef]

14. Wang, Y.; Zhou, L.; Ping, X.; Jia, Q.; Li, R. Ten-year variability and environmental controls of ecosystem water use efficiency in a rainfed maize cropland in Northeast China. Field Crop. Res. 2018, 226, 48-55. [CrossRef]

15. Gang, C.; Wang, Z.; Zhou, W.; Chen, Y.; Li, J.; Chen, J.; Qi, J.; Odeh, I.; Groisman, P.Y. Assessing the Spatiotemporal Dynamic of Global Grassland Water Use Efficiency in Response to Climate Change from 2000 to 2013. J. Agron. Crop. Sci. 2016, 202, 343-354. [CrossRef]

16. Jiang, Y.; Still, C.J.; Rastogi, B.; Page, G.F.M.; Wharton, S.; Meinzer, F.C.; Voelker, S.; Kim, J.B. Trends and controls on water-use efficiency of an old-growth coniferous forest in the Pacific Northwest. Environ. Res. Lett. 2019, 14, 074029. [CrossRef]

17. Liu, X.; Chen, X.; Li, R.; Long, F.; Zhang, L.; Zhang, Q.; Li, J. Water-use efficiency of an old-growth forest in lower subtropical China. Sci. Rep. 2017, 7, 42761. [CrossRef] [PubMed]

18. Tang, X.; Li, H.; Xu, X.; Luo, J.; Li, X.; Ding, Z.; Xie, J. Potential of MODIS data to track the variability in ecosystem water-use efficiency of temperate deciduous forests. Ecol. Eng. 2016, 91, 381-391. [CrossRef]

19. Xie, J.; Chen, J.; Sun, G.; Zha, T.; Yang, B.; Chu, H.; Liu, J.; Wan, S.; Zhou, C.; Ma, H.; et al. Ten-year variability in ecosystem water use efficiency in an oak-dominated temperate forest under a warming climate. Agric. For. Meteorol. 2016, 218-219, 209-217. [CrossRef]

20. Guo, L.; Sun, F.; Liu, W.; Zhang, Y.; Wang, H.; Cui, H.; Wang, H.; Zhang, J.; Du, B. Response of Ecosystem Water Use Efficiency to Drought over China during 1982-2015: Spatiotemporal Variability and Resilience. Forests 2019, 10, 598. [CrossRef]

21. Tang, X.; Ma, M.; Ding, Z.; Xu, X.; Yao, L.; Huang, X.; Gu, Q.; Song, L. Remotely Monitoring Ecosystem Water Use Efficiency of Grassland and Cropland in China's Arid and Semi-Arid Regions with MODIS Data. Remote Sens. 2017, 9, 616. [CrossRef]

22. Wang, L.; Li, M.; Wang, J.; Li, X.; Wang, L. An analytical reductionist framework to separate the effects of climate change and human activities on variation in water use efficiency. Sci. Total Environ. 2020, 727, 138306. [CrossRef]

23. Zhao, J.; Xu, T.; Xiao, J.; Liu, S.; Mao, K.; Song, L.; Yao, Y.; He, X.; Feng, H. Responses of Water Use Efficiency to Drought in Southwest China. Remote Sens. 2020, 12, 199. [CrossRef]

24. Zheng, H.; Lin, H.; Zhou, W.; Bao, H.; Zhu, X.; Jin, Z.; Song, Y.; Wang, Y.; Liu, W.; Tang, Y. Revegetation has increased ecosystem water-use efficiency during 2000-2014 in the Chinese Loess Plateau: Evidence from satellite data. Ecol. Indic. 2019, 102, 507-518. [CrossRef]

25. Sun, S.; Song, Z.; Wu, X.; Wang, T.; Wu, Y.; Du, W.; Che, T.; Huang, C.; Zhang, X.; Ping, B.; et al. Spatio-temporal variations in water use efficiency and its drivers in China over the last three decades. Ecol. Indic. 2018, 94, 292-304. [CrossRef]

26. Lu, Y.; Zhang, X.; Chen, S.; Shao, L.; Sun, H. Changes in water use efficiency and water footprint in grain production over the past 35 years: A case study in the North China Plain. J. Clean Prod. 2016, 116, 71-79. [CrossRef]

27. Liu, N.; Kala, J.; Liu, S.; Haverd, V.; Dell, B.; Smettem, K.R.J.; Harper, R.J. Drought can offset potential water use efficiency of forest ecosystems from rising atmospheric CO2. J. Environ. Sci. 2020, 90, 262-274. [CrossRef]

28. Lu, X.; Chen, M.; Liu, Y.; Miralles, D.G.; Wang, F. Enhanced water use efficiency in global terrestrial ecosystems under increasing aerosol loadings. Agric. For. Meteorol. 2017, 237-238, 39-49. [CrossRef]

29. El Masri, B.; Schwalm, C.; Huntzinger, D.N.; Mao, J.; Shi, X.; Peng, C.; Fisher, J.B.; Jain, A.K.; Tian, H.; Poulter, B.; et al. Carbon and Water Use Efficiencies: A Comparative Analysis of Ten Terrestrial Ecosystem Models under Changing Climate. Sci. Rep. 2019, 9, 14680. [CrossRef]

30. Sterling, S.M.; Ducharne, A.; Polcher, J. The impact of global land-cover change on the terrestrial water cycle. Nat. Clim. Chang. 2012, 3, 385-390. [CrossRef]

31. Du, X.; Zhao, X.; Zhou, T.; Jiang, B.; Xu, P.; Wu, D.; Tang, B. Effects of Climate Factors and Human Activities on the Ecosystem Water Use Efficiency throughout Northern China. Remote Sens. 2019, 11, 2766. [CrossRef]

32. Guo, L.; Shan, N.; Zhang, Y.; Sun, F.; Liu, W.; Shi, Z.; Zhang, Q. Separating the effects of climate change and human activity on water use efficiency over the Beijing-Tianjin Sand Source Region of China. Sci. Total Environ. 2019, 690, 584-595. [CrossRef]

33. Huang, S.W.; Kong, J.M. Assessing Land Degradation Dynamics and Distinguishing Human-Induced Changes from Climate Factors in the Three-North Shelter Forest Region of China. Isprs Int. J. Geo. Inf. 2016, 5, 158. [CrossRef]

34. Yang, F.; Yang, M. Greening the one belt and one road initiative. Mitig Adapt. Strat Gl. 2019, 24, 735-748. [CrossRef] 
35. Ahmad, F.; Draz, M.U.; Su, L.; Ozturk, I.; Rauf, A. Tourism and Environmental Pollution: Evidence from the One Belt One Road Provinces of Western China. Sustainability 2018, 10, 3520. [CrossRef]

36. Li, F.; Zhang, S.W.; Yuan, K.Y. Land use change in farming-pastoral ecotone and its effects on ecosystem services value: A case study in West Jilin, China. Hum. Ecol Risk Assess. 2018, 24, 551-566.

37. Xie, X.; Liang, S.; Yao, Y.; Jia, K.; Meng, S.; Li, J. Detection and attribution of changes in hydrological cycle over the Three-North region of China: Climate change versus afforestation effect. Agric. For. Meteorol. 2015, 203, 74-87. [CrossRef]

38. Cao, S. Why large-scale afforestation efforts in China have failed to solve the desertification problem. Environ. Sci. Technol. 2008, 42, 1826-1831. [CrossRef]

39. Cao, S. Impact of Spatial and Temporal Scales on Afforestation Effects: Response to Comment on "Why Large-Scale Afforestation Efforts in China Have Failed to Solve the Desertification Problem". Environ. Sci. Technol. 2008, 42, 7724-7725. [CrossRef]

40. Cao, S. Response to Comment on "Why Large-Scale Afforestation Efforts in China Have Failed to Solve the Desertification Problem". Environ. Sci. Technol. 2008, 42, 8166. [CrossRef]

41. Liu, X. Comment on "Why Large-Scale Afforestation Efforts in China Have Failed to Solve the Desertification Problem". Environ. Sci. Technol. 2008, 42, 8165. [CrossRef]

42. Yang, X.; Ci, L. Comment on "Why Large-Scale Afforestation Efforts in China Have Failed To Solve the Desertification Problem". Environ. Sci. Technol. 2008, 42, 7722-7723. [CrossRef]

43. Yuan, W.P.; Liu, S.G.; Yu, G.R.; Bonnefond, J.M.; Chen, J.Q.; Davis, K.; Desai, A.R.; Goldstein, A.H.; Gianelle, D.; Rossi, F.; et al. Global estimates of evapotranspiration and gross primary production based on MODIS and global meteorology data. Remote Sens. Environ. 2010, 114, 1416-1431. [CrossRef]

44. Yao, Y.; Liang, S.; Li, X.; Hong, Y.; Fisher, J.B.; Zhang, N.; Chen, J.; Cheng, J.; Zhao, S.; Zhang, X.; et al. Bayesian multimodel estimation of global terrestrial latent heat flux from eddy covariance, meteorological, and satellite observations. J. Geophys. Res. Atmos. 2014, 119, 4521-4545. [CrossRef]

45. Peng, S.; Ding, Y.; Liu, W.; Li, Z. 1 km monthly temperature and precipitation dataset for China from 1901 to 2017. Earth Syst. Sci. Data 2019, 11, 1931-1946. [CrossRef]

46. Liu, X.; Feng, X.; Fu, B. Changes in global terrestrial ecosystem water use efficiency are closely related to soil moisture. Sci. Total Environ. 2020, 698, 134165. [CrossRef] [PubMed]

47. Zhang, Y.; Song, C.; Sun, G.; Band, L.E.; McNulty, S.; Noormets, A.; Zhang, Q.; Zhang, Z. Development of a coupled carbon and water model for estimating global gross primary productivity and evapotranspiration based on eddy flux and remote sensing data. Agric. For. Meteorol. 2016, 223, 116-131. [CrossRef]

48. Sun, Y.; Piao, S.; Huang, M.; Ciais, P.; Zeng, Z.; Cheng, L.; Li, X.; Zhang, X.; Mao, J.; Peng, S.; et al. Global patterns and climate drivers of water-use efficiency in terrestrial ecosystems deduced from satellite-based datasets and carbon cycle models. Glob. Ecol. Biogeogr. 2016, 25, 311-323. [CrossRef]

49. Yang, S.; Zhang, J.; Zhang, S.; Wang, J.; Bai, Y.; Yao, F.; Guo, H. The potential of remote sensing-based models on global water-use efficiency estimation: An evaluation and intercomparison of an ecosystem model (BESS) and algorithm (MODIS) using site level and upscaled eddy covariance data. Agric. For. Meteorol. 2020, 287, 107959. [CrossRef]

50. Zhu, X.-J.; Yu, G.-R.; Wang, Q.-F.; Hu, Z.-M.; Zheng, H.; Li, S.-G.; Sun, X.-M.; Zhang, Y.-P.; Yan, J.-H.; Wang, H.-M.; et al. Spatial variability of water use efficiency in China's terrestrial ecosystems. Glob. Planet. Chang. 2015, 129, 37-44. [CrossRef]

51. Li, G.; Chen, W.; Li, R.; Zhang, X.; Liu, J. Assessing the spatiotemporal dynamics of ecosystem water use efficiency across China and the response to natural and human activities. Ecol. Indic. 2021, 126, 107680. [CrossRef]

52. Zhao, A.; Zhang, A.; Cao, S.; Feng, L.; Pei, T. Spatiotemporal patterns of water use efficiency in China and responses to multi-scale drought. Appl. Clim. 2020, 140, 559-570. [CrossRef]

53. Salazar-Moreno, R.; Rojano-Aguilar, A.; Lopez-Cruz, I.L. Water Use Efficiency in Controlled Agriculture. Tecnol. Cienc. Agua 2014, 5, 177-183.

54. Stroosnijder, L.; Moore, D.; Alharbi, A.; Argaman, E.; Biazin, B.; van den Elsen, E. Improving water use efficiency in drylands. Curr. Opin. Environ. Sust. 2012, 4, 497-506. [CrossRef]

55. Rufi-Salis, M.; Petit-Boix, A.; Villalba, G.; Sanjuan-Delmas, D.; Parada, F.; Ercilla-Montserrat, M.; Arcas-Pilz, V.; Munoz-Liesa, J.; Rieradevall, J.; Gabarrell, X. Recirculating water and nutrients in urban agriculture: An opportunity towards environmental sustainability and water use efficiency? J. Clean Prod. 2020, 261, 121213. [CrossRef]

56. Liu, Y.Q.; Song, W. Modelling crop yield, water consumption, and water use efficiency for sustainable agroecosystem management. J. Clean Prod. 2020, 253, 119940. [CrossRef]

57. Onishi, A.; Sato, Y.; Watanabe, T.; Fukushima, Y.; Cao, X.; Imura, H.; Matsuoka, M.; Morisugi, M. Study on Sustainable Agricultural Production and Agricultural Water Use Efficiency in the Yellow River Basin of China; CRC Press Taylor \& Francis Group: Kyoto, Japan, 2009; pp. 465-470.

58. Ma, X.H.; Feng, Q.; Su, Y.H.; Yu, T.F.; Deo, R.C. Characteristics of ecosystem water use efficiency in a desert riparian forest. Environ. Earth Sci. 2018, 77, 358. [CrossRef]

59. Emmerich, W.E. Ecosystem water use efficiency in a semiarid shrubland and grassland community. Rangel. Ecol. Manag. 2007, 60, 464-470. [CrossRef] 
60. Liu, Y.B.; Xiao, J.F.; Ju, W.M.; Zhou, Y.L.; Wang, S.Q.; Wu, X.C. Water use efficiency of China's terrestrial ecosystems and responses to drought. Sci. Rep. 2015, 5, 13799. [CrossRef]

61. Li, Y.; Shi, H.; Zhou, L.; Eamus, D.; Huete, A.; Li, L.; Cleverly, J.; Hu, Z.; Harahap, M.; Yu, Q.; et al. Disentangling Climate and LAI Effects on Seasonal Variability in Water Use Efficiency Across Terrestrial Ecosystems in China. J. Geophys Res. Biogeosci. 2018, 123, 2429-2443. [CrossRef] 